\title{
THE INFLUENCE OF SUKSES BER-KB COUNSELING TOOL TO KNOWLEDGE OF ORAL CONTRACEPTIVE ACCEPTORS AT PHARMACIES IN MALANG
}

\author{
HANANDITIA R PRAMESTUTIE*, RATNA K ILLAHI, HIDAYAH S PERDANASTUTI, AYUK L HARIADINI, LATHIFAH H \\ Department of Community Pharmacy, Study Program of Pharmacy, Faculty of Medicine, Brawijaya University, Jalan Veteran Malang, \\ Indonesia. Email: hananditia@ub.ac.id/hananditia@gmail.com
}

Received: 20 June 2017, Revised and Accepted: 14 December 2017

\section{ABSTRACT}

Objective: The use of oral contraceptive requires specific instructions. Pharmacist, as a part of healthcare provision, is able to counsel their clients about the proper use of oral contraceptive to be successful in family planning program. Pharmacist must be able to explain what acceptors should do if she misses pills and possible side effects because side effects are the most common reasons for women discontinuing combined oral contraceptive (COC). Therefore, counseling is an important part of family planning service. To provide more effective counseling, this study used "Sukses Ber-KB" computer application as a counseling tool. We aimed to determine the effect of this tool on improving the knowledge of oral contraceptive acceptors interviewed at pharmacies in Malang.

Methods: Pharmacy selection was done by cluster random sampling based on the five districts of Malang, while acceptors were selected using a purposive sampling method, resulting in 106 COC acceptors. This study comprises pre-experimental research (one group pretest-posttest) with a cross-sectional study design, the analysis using Wilcoxon test.

Results: The analysis of the results using a Wilcoxon test showed a significance value of 0 ( $\mathrm{p}<0.05$ ). The study sought to determine change in the contraceptive users knowledge scores about COC s following counseling with the Sukses Ber-KB counseling tool. The results also showed 105 positive score changes (increased knowledge) and 1 tie.

Conclusion: It is concluded that the use of the Sukses Ber-KB counseling tool showed significant increase in the users' knowledge about oral contraceptives with $\mathrm{p}<0.05$.

Key words: Acceptors knowledge, Counseling tool, “Sukses Ber-KB,” Oral contraceptive.

(C) 2018 The Authors. Published by Innovare Academic Sciences Pvt Ltd. This is an open access article under the CC BY license (http://creativecommons. org/licenses/by/4. 0/) DOI: http://dx.doi.org/10.22159/ajpcr.2018.v11i4.23408

\section{INTRODUCTION}

Oral contraceptives are medications that prevent pregnancy. One of the most commonly used forms is the birth control pill, a hormonally-based combined oral contraceptive (COC). Oral contraceptives may contain combinations of the hormones estrogen and progestin or progestin alone. These hormones are similar to those naturally produced by women's ovaries. Oral contraceptives are taken by mouth every day and when taken properly can prevent pregnancy $[1,2]$.

COCs are the most common reversible method of birth control in developing countries. About 150 million women use this method. Indonesia has a family planning program that offers various types of contraceptives such as intrauterine devices, condoms, pills, and injectable and implantable progestin. However, most Indonesian women use oral contraceptives to prevent pregnancy $[3,4]$.

Pharmacy services, which originally focused only on the management of drugs, have developed into a combination of drug services and clinical pharmacy services that aim to improve patient's life quality. Pharmacists are required to improve their knowledge, skills, and behaviors to be able to interact directly with patients. One such interaction is the provision of drug information and counseling of patients. For example, patients often require counseling about the safe and effective use of oral contraceptives to avoid mistakes and to achieve successful family planning $[5,6]$.

The successful use of oral contraceptives requires a high degree of discipline to consistently take pills on schedule. Indiscipline in the use of oral contraceptives is expected to increase the number of contraceptive failures and side effects. Therefore, counseling plays an integral and very important part in family planning services $[5,7]$.

To be more effective, pharmacists can use counseling tools, including audiovisual formats. One such counseling tool based on a computer application is the Sukses Ber-KB, it is developed in Study Program of Pharmacy, Faculty of Medicine, Brawijaya University. It contains definitions and types of oral contraceptives, as well as explanations of how they work, proper use, side effects, interactions, and the criteria for oral contraceptive users, including the menstrual cycle.

With the utilization of the "Sukses Ber-KB" application as a counseling tool, researchers expect to get an overview of oral contraceptive users' knowledge before and after they receive counseling. In addition, oral contraceptive users are also expected to gain knowledge and a better understanding of the correct use of oral contraceptives and to be able to overcome problems that arise during oral contraceptive use, so as to reduce the risk of unplanned pregnancies.

\section{METHODS}

This pre-experimental study with a one-group pretest-posttest design utilized a cross-section of the entire population of oral contraceptive users who came to pharmacies in the city of Malang, to buy oral contraceptives or to consult a pharmacist during the January-April 2015 period. This study was reviewed by the Health Study Ethics Committee of the Medical Faculty of Brawijaya University and declared as ethically appropriate with number 694/EC/KEPK-S1-FARM/12/2014.

The samples in this study comprised oral contraceptive users and the pharmacies where research was conducted. Purposive sampling was 
applied in the sampling of users, while stratified random sampling was used for pharmacy selection. The minimum sample size of 106 users in this study was calculated using the Slovin formula [8].

The inclusion criteria for respondents in the study were the users of COCs who came to the pharmacy to buy COCs and were willing to fill out a questionnaire. Exclusion criteria were the users of oral contraceptive mini pills or emergency oral contraceptives, and family members of oral contraceptive users who received counseling.

All participants patient who met the inclusion criteria were given an explanation regarding voluntary participation in the study and were then asked to fill out and sign an informed consent form. Patients completed a questionnaire with guidance from the researchers for data collection.

The instruments used in this study were (i) the Sukses Ber-KB counseling tool and (ii) a questionnaire to measure the users' knowledge of oral contraceptives. The questionnaire comprised 10 questions regarding the definition of COCs, how they work, proper use, side effects, and criteria for oral contraceptive users. The questionnaire also acquired provided additional data such as age, education, and occupation, as well as the duration of oral contraceptive use and information resources accessed. The Sukses Ber-KB application was utilized by the respondent to complete the questionnaire, before and after counseling.

There were three possible answers for each question and users' were asked to select one correct answer. The same questionnaire was used for the pre-test and post-test phases of the study. The total questionnaire

Table 1: Demographic data frequency distribution of acceptors at 18 pharmacies in the city of Malang

\begin{tabular}{ll}
\hline Characteristics & Frequency (n) (\%) \\
\hline Age (year) & $21(19.80)$ \\
$20-29$ & $52(49.10)$ \\
$30-39$ & $29(27.40)$ \\
$40-49$ & $4(3.80)$ \\
250 & $6(5.70)$ \\
Education level & $23(21.70)$ \\
Not completed elementary school & $37(34.90)$ \\
Elementary school graduates & $33(31.10)$ \\
Junior high school graduates & $7(6.60)$ \\
Senior high school graduates & \\
Bachelor degree & $17(16.00)$ \\
Occupation & $12(11.30)$ \\
Private employee & $68(64.20)$ \\
Entrepreneur & \\
Housewife & $1(0.90)$ \\
Other: & $6(5.70)$ \\
Laundry worker & $1(0.90)$ \\
Factory worker & $1(0.90)$ \\
Honorary teacher & \\
Tailor & $12(11.30)$ \\
Oral contraceptive use duration (months) & $5(4.70)$ \\
0-6 & $14(13.20)$ \\
6-12 & $12(11.30)$ \\
1-2 & $63(59.40)$ \\
2-3 & \\
$>3$ & $2(1.90)$ \\
Oral contraceptive information resources & $78(73.60)$ \\
Pharmacist & $5(4.70)$ \\
Midwife & $1(0.90)$ \\
Obstetricians & $5(4.70)$ \\
Others: & $6(5.70)$ \\
Non-government organization & $3(2.80)$ \\
Relatives & $2(1.90)$ \\
Neighbor & $4(3.80)$ \\
Mass media & \\
Self-study & \\
Friends & \\
\hline
\end{tabular}

score for each user before and after counseling was calculated and then analyzed using the Wilcoxon test.

Before the questionnaires were administered, the reliability and validity of the questionnaires were tested with 30 users outside of the study sample, according to the inclusion and exclusion criteria. The data obtained then been tested using SPSS software.

\section{RESULTS}

\section{Demographic data}

This study was conducted at 18 pharmacies in the city of Malang selected by stratified random sampling: Five pharmacies in the district of Klojen, four in Blimbing (4), three in Kedungkandang (3), Sukun (3), and Lowokwaru (3). The sample size of 106 respondents was derived from the districts as follows: 29 from Sukun, 25 from Lowokwaru, 12 from Klojen, 25 from Kedungkandang, and 15 from Blimbing.

An analysis was conducted of additional data regarding the patients' characteristics such as age, education, and occupation, as well as the duration of oral contraceptive use and information resources accessed.

Most patients ( $n=52,49.1 \%)$ were in the 30-39 year age group. The highest level of education for the majority ( $n=37,34.9 \%$ ) of COC users was graduation from junior high school. Most patients $(n=68,64.20 \%)$ were housewives. More than half of patients ( $n=63,53.94 \%$ ) had used oral contraceptives for 3 years. 78 users $(73.6 \%)$ obtained information about oral contraceptives from a midwife for detail see Table 1.

\section{Patient knowledge regarding COCs}

Users' knowledge about COCs was measured using a reliable and valid questionnaire that was declared as ethically appropriate. A Wilcoxon test was used to determine knowledge gaps before and after counseling using the Success Ber-KB application.

The table above indicates that of the 106 respondents, 105 had higher scores after counseling than before counseling; only one respondent had the same score before and after counseling. Differences in users' knowledge before and after Sukses Ber-KB counseling were shown to be highly significant, in favor of improved knowledge following counseling with the Sukses Ber-KB computer application $(\mathrm{p}<0.001)$ for detail see Table 2 and 3.

\section{DISCUSSION}

A pre-experimental study with pretest-posttest design had been conducted to determine the effect of the use of "Sukses Ber-KB" application to the acceptors knowledge of oral contraceptives in pharmacies in the city of Malang.

Two instruments were used in this study: A counseling tool and a questionnaire. The counseling tool used in this study was the computer application Sukses Ber-KB which was equipped with images and

Table 2: Wilcoxon test result

\begin{tabular}{lll}
\hline Data & Significance value & Remarks \\
\hline $\begin{array}{l}\text { Differences in the acceptor's } \\
\text { knowledge before and after }\end{array}$ & & Significant \\
"Sukses Ber-KB" counseling & & \\
\hline
\end{tabular}

Table 3: Score ranks

\begin{tabular}{lll}
\hline Data & Remarks & $\begin{array}{l}\text { Number of } \\
\text { acceptors }\end{array}$ \\
\hline $\begin{array}{l}\text { After “Sukses Ber-KB" } \\
\text { counseling - before "Sukses }\end{array}$ & Negative Change & 0 \\
Ber-KB" counseling & & \\
& Positive Change & 105 \\
& Tie & 1 \\
& Total & 106 \\
\hline
\end{tabular}


explanations of oral contraceptives. A questionnaire was used to measure the respondents' knowledge of oral contraceptives before and after counseling using the Sukses Ber-KB application.

Most users of COCs were in the age range of 30-39 years (49.1\%), which includes the principal reproductive years for women. The Badan Koordinasi Keluarga Berencana Nasional, well known as The National Population and Family Planning Board stated that women of childbearing age were aged 15-49, either married, unmarried, or widowed. The lower percentage of women $(19.8 \%)$ in the younger childbearing age range, i.e., 20-29 years, can be interpreted as women in the early stages of the fertile period who, therefore, circumscribe the family planning program. In the older age range, i.e., $40-49$ years, the percentage is also low $(27.4 \%)$ because these women may assume that they are not sufficiently fertile or believe that they are infertile. The lowest percentage $(3.8 \%)$ of COCs users was $>50$ years since women in this age range have entered menopause. In a regional survey of seven countries in Southeast Asia, the average age of menopause was indicated as 51.1 years $[4,9]$.

The highest level of education achieved by COCs user's varied considerably. Highest education level was used to determine how much respondents knew about COCs. Higher education levels resulted in easier comprehension of the information, and subsequently, greater knowledge. The highest level achieved by the majority of respondents $(\mathrm{n}=37,34.9 \%$ ) was junior high school graduation. According to the theory, respondents with higher education levels would have more knowledge and be able to comprehend information more easily. However, after counseling using the Success Ber-KB application, respondents with all levels of education experienced COC knowledge enhancement. From previous study showed that the degree of knowledge enhancement varied and was dependent on the highest level of education they completed. With the enhanced knowledge, it is expected that oral contraceptive users would be more compliant in their use of COCs to ensure successful family planning $[10,11]$.

This study found that most COCs users were housewives ( $\mathrm{n}=68,64.2 \%)$. The responsibilities and busy life associated with working may cause a person to forget other activities outside of work. Therefore, the data obtained indicate that housewives are the largest users of COCs because they are not too busy to be capable of taking COCs every day.

The duration of oral contraceptive use was quite diverse. The largest percentage of COC use was more than 3 years $(n=63,59.4 \%)$. The duration of $\mathrm{COC}$ use can be associated with user's knowledge about COCs since duration can be affected by a woman's experience of using COCs for a long time. Experience is one factor that affects people's level of knowledge, causing enabling better analysis and synthesis abilities. Better level of knowledge would lead to better ability to analyze and synthesize information $[10,11]$.

Most respondents ( $\mathrm{n}=78,73.60 \%)$ first received information about COCs from midwives. Basic Health Research (Riskesdas) results in 2013 show that most people (52.5\%) obtain family planning services in the private sector from midwives who practice independently [11]. Government service facilities, such as hospitals, health centers, and village health posts, were utilized by $23.9 \%$ of users. Postpartum family planning services, as well as family planning services in general, can be provided by competent doctors and midwives. In the case of services performed by midwives, the Ministry of Health No. 1464/Menkes/ PER/IX/2010, Article 12 concerning the license and implementation of midwifery practices, states that a midwife can 1) provide counseling regarding the reproductive health of women and family planning and 2) provide oral contraceptives and condoms $[4,12,13]$.

COCs are one type of contraception that must be taken every day. Adequate knowledge about oral contraceptives will affect a user's compliance in taking them. Some of the constraints experienced by the users of oral contraceptives are that oral contraceptives must be taken every day, forgetting how to take the medicine, not knowing how to properly handle the medication (i.e., the different pill colors in the package of 28 tablets may cause confusion about which pill users should start taking), and exposure to the side effects of oral contraceptive use. The existence of these constraints can lead to lower compliance by users of oral contraceptives. Constraints experienced by the user can be solved by useful counseling to help prevent or minimize drug-related problems and improve the patient's ability to solve problems in terms of therapy $[10,14]$. Counseling tools in the form of a computer application, such as the Sukses Ber-KB, may be used by pharmacists to explain oral contraceptives. Using this tool with visual images, counseling can be more interesting and the material presented will be more easily comprehended than if pharmacists only provide a verbal explanation, since users can also see a visual explanation. Therefore, use of this application is expected to enhance the knowledge of compliant users and to also have an impact on improving conformity for less compliant users.

In accordance with the counseling aspect of the Indonesian Ministry of Health, the Sukses Ber-KB counseling tool includes information on the active substance content, schedule and method of use, and mechanisms of drug action, as well as the unwanted potential effects of COCs. To determine user knowledge about oral contraceptives, researchers used a questionnaire consisting of 10 items with three possible answers and respondents were asked to choose the one most correct answer. Users of oral contraceptives filled out questionnaires before and after counseling with the Sukses Ber-KB application.

The results of pre-test questionnaire indicated varied answers because users had little knowledge of oral contraceptives, and therefore, they answered questions according to their knowledge or perceptions. Many respondents chose not to answer some of the questions because they really did not know the answer.

The results of the post-test questionnaire revealed little variance in the answers after users was given counseling with the Sukses BerKB application. Most respondents provided the correct answers, but there were several users who still answered incorrectly. Only two of the respondents did not provide answers to the first question, and one respondent did not give an answer to the second question, possibly because the respondent forgot the correct answers or was less convinced and still confused by the choice of answers. The low variance in responses shows that the users' knowledge of COCs increased after counseling with the Sukses Ber-KB application, so they could answer the questions correctly. To determine the normality of the data, the Kolmogorov-Smirnov test was applied using IBM SPSS 20 software because the sample size in this study was large ( $>50$ respondents). The test indicated that the data for the pre-test and post-test questionnaire results were abnormally distributed at a significance level $p<0.05$. As the data were abnormally distributed, the parametric test requirement could not be met. The alternative was to apply a non-parametric test, i.e., the Wilcoxon test.

The Wilcoxon test results indicate a significance level of 0.000 , which is $\mathrm{p}<0.05$; therefore, the null hypothesis (H0) can be rejected. Thus, it can be concluded that there were differences in the COCs users' knowledge levels before and after counseling with the Sukses Ber-KB.

The results indicate that 105 respondents had higher scores after counseling than before counseling. Only one respondent had the same score before and after counseling because she did not have much time and hurried when answering the post-test questionnaire, so her pretest answers exactly matched the answers to the post-test, causing no increase in the score before and after counseling.

The increase in the questionnaire scores before and after counseling fulfills the aim of the study to determine the effect of the use of the Sukses Ber-KB counseling tool on the knowledge of COC users in 
pharmacies in the city of Malang. The results prove that the Sukses BerKB application enhanced users' knowledge about COCs. In addition, the benefits of counseling, according to the Indonesian Ministry of Health, to provide additional explanations and to help solve therapy problems in certain situations can also be achieved.

The use of a computer-based counseling tool was proven to enhance COCs users' knowledge. Therefore, counseling using this method is appropriate for improving the knowledge of users and can be applied by pharmacists in counseling in both pharmacies and in healthcare facilities. User's knowledge is one factor that determines the success of contraception use. Higher levels of knowledge result in compliance in taking birth control pills. Knowledge has an influence in shaping behavior and compliance is an action relating to a person's behavior, so that knowledge is a very important domain for shaping a person's actions, in this case, medication compliance by users of the pill [1517].

Limitation of this study is counseling tool was only applied once. The participants (acceptors oral contraception) did not retain the knowledge 1 month following counseling.

\section{CONCLUSION}

The Sukses Ber-KB application implemented as a counseling tool was shown to significantly enhance the knowledge of COC users.

\section{ACKNOWLEDGMENTS}

We are grateful to Research Development Unit, Medical Faculty, Brawijaya University, Education Ministry of Indonesia.

\section{AUTHORS' CONTRIBUTIONS}

Hananditia R. Pramestutie, Ratna K. Illahi, Hidayah S. Perdanastuti, Ayuk L. Hariadini: Conceived of the presented idea. Hananditia R. Pramestutie, Ratna K. Illahi: Developed the theory and performed the computations. Hidayah S. Perdanastuti, Ayuk L. Hariadini: Verified the analytical methods. Hidayah S. Perdanastuti, Lathifah H: Carried out the experiment. All authors discussed the results and contributed the final manuscript

\section{CONFLICTS OF INTEREST}

No conflicts of Interests.

\section{REFERENCES}

1. Kelli S, Katharine W, Nancy R, Carolyn W. Studying the use of oral contraceptive: A review of measurement approaches. J Women's Health 2010;19:2203-10.

2. Gilliam M, Knight S, McCarthy M Jr. Success with oral contraceptives: A pilot study. Contraception 2004;69:413-8.

3. Kisok K, Hyejin P. Demographic factors associated with oral contraceptive use in korean women. Int J Pharm Pharm Sci 2016;8:299-301.

4. Kementerian Kesehatan RI. Rencana Aksi Nasional Pelayanan Keluarga Berencana 2014-2015. Jakarta: Direktorat Jenderal Bina Gizi dan Kesehatan Ibu dan Anak; 2013.

5. Moreau C, Bajos N, Trussell J. The impact of pharmacy access to emergency contraceptive pills in France. Contraception 2006;73:602-8.

6. Eickhoff C, Schulz M. Pharmaceutical care in community pharmacies: Practice and research in germany. Ann Pharmacother 2006;40:729-35.

7. Frost JJ, Singh S, Finer LB. U.S. Women's one-year contraceptive use patterns, 2004. Perspect Sex Reprod Health 2007;39:48-55.

8. Sastroasmoro S, Ismael S. Dasar-Dasar Metodologi Penelitian Klinis. Jakarta: Sagung Seto; 2011.

9. Palacios S, Henderson VW, Siseles N, Tan D, Villaseca P. Age of menopause and impact of climacteric symptoms by geographical region. Climacteric 2010;13:419-28.

10. Al-Shaikh GK, Mayet AY, Alshaikh MK, Hamad AF, Mahmoud MA, Aljadhey HS, et al. Knowledge on adherence and safety of the oral contraceptive pill in Saudi women. Saudi Med J 2012;33:665-70.

11. Machado RB, de Melo NR, Prota FE, Lopes GP, Megale A. Women's knowledge of health effects of oral contraceptives in five Brazilian cities. Contraception 2012;86:698-703.

12. Kementerian Kesehatan RI. Situasi Keluarga Berencana di Indonesia. Jakarta: Buletin Jendela Data dan Informasi Kesehatan; 2013.

13. Menteri Kesehatan Republik Indonesia. Peraturan Menteri Kesehatan Republik Indonesia Nomor 35 Tahun 2014 tentang Standar Pelayanan Kefarmasian Di Apotek. Jakarta: Departemen Kesehatan; 2014.

14. Halpern V, Grimes DA, Lopez L, Gallo MF. Strategies to improve adherence and acceptability of hormonal methods for contraception. Cochrane Database Syst Rev 2006;1:CD004317.

15. Anderson C, Blenkinsopp A. Community pharmacy supply of emergency hormonal contraception: A structured literature review of international evidence. Hum Reprod 2006;21:272-84.

16. Davis TC, Fredrickson DD, Potter L, Brouillette R, Bocchini AC, Williams MV, et al. Patient understanding and use of oral contraceptive pills in a southern public health family planning clinic. South Med J 2006;99:713-8.

17. Huma A, Farya Z, Shazia A, Neelam M, Hina H, Ghazala R, et al. Integration of community setup in pharmaceutical care: Current challenges, perception, facts and opportunities in Pakistan. Int J Pharm Pharm Sci 2016;8:138-43. 